\title{
Adsorption of Chromium(VI) and Zinc(II) Ions on the Skin of Orange Peels (Citrus sinensis)
}

\author{
O. A. Ekpete ${ }^{*}$, F. Kpee, J. C. Amadi and R. B. Rotimi \\ Department of Chemistry, Rivers State University of Education, P.M.B 5047 Port Harcourt. Nigeria. \\ e-mail: oekpete@yahoo.com
}

\begin{abstract}
The removal of heavy metal ions $\mathrm{Cr}$ (VI) and Zn (II) from aqueous solution using the skin of orange peel (Citrus sinensis) as an adsorbent under different experimental conditions was investigated in this study. The concentrations of the metal ions adsorbed were determined by atomic absorption spectroscopic (AAS) method. The parameters investigated were temperature, contact time, adsorbent dosage, initial metal ions concentration and $\mathrm{pH}$. It was observed that the white inner skin of orange removed more of $\mathrm{Cr}(\mathrm{VI})$ than $\mathrm{Zn}$ (II) metal ions in all the adsorption experiments. The optimum removal of the $\mathrm{Cr}(\mathrm{VI})$ and $\mathrm{Zn}(\mathrm{II})$ metal ions occurred at $\mathrm{pH} 3$ and at temperature $30^{\circ} \mathrm{C}$. Application of the Langmuir isotherm to the systems yielded maximum adsorption capacity of $8.068(\mathrm{mg} / \mathrm{g})$ and $1.078(\mathrm{mg} / \mathrm{g})$ for $\mathrm{Cr}(\mathrm{VI})$ and $\mathrm{Zn}$ (II) metal ions respectively.
\end{abstract}

Keywords: Orange peel, Adsorption, Heavy metals, Langmuir.

\section{Introduction}

Agricultural waste products such as orange peel (Citrus sinensis), that are available at little or no cost have been reported to be capable of removing substantial amounts of metal ions from aqueous solution. ${ }^{1,2}$ Due to rapid development and industrialization in many countries, the levels of industrial pollution have been steadily rising. The pollution problem of industrial wastewater remains a topic of global concern. This is because wastewater collected from municipalities, communities and industries must ultimately be returned to receiving waters or to the land. ${ }^{3,4}$ Trace elements play essential roles in biological processes, but at higher concentrations they may be toxic to the biota and they disturb the biochemical processes and cause hazards. These elements include metals $(\mathrm{Cd}, \mathrm{Cr}, \mathrm{Co}, \mathrm{Cu}, \mathrm{Zn}, \mathrm{Pd}, \mathrm{Ni}$, and $\mathrm{Ag}$ ) and metalloids ( $\mathrm{Se}, \mathrm{AS}, \mathrm{Sb}$ ). Most of the trace elements are transition metals with variable oxidation states and coordination numbers. These metals form complexes with organics in the environment thereby increasing their mobility in the biota and manifest toxic effects. Trace metal pollution in the aquatic environment is a major health problem. Man's exposure to trace metals comes from industrial activities like mining, smelting, refining and manufacturing processes. $5,6,7,8$

"Corresponding author 
Heavy metal pollution of wastewater is a common environmental hazard, since the toxic metal ions dissolved can ultimately reach the top of the food chain and thus become a risk factor for human health. These metals are present in the wastewaters of several industries such as metal cleaning and plating baths, refineries, paper and pulp, tanning industries etc. ${ }^{9,10}$ The excessive intake of metal by man leads to severe mucosal irritation, widespread capillary damage, hepatic and renal damage, central nervous problems followed by depression, gastrointestinal irritation and possible necrotic changes in the liver and kidney. These metals are toxic both in chemically combined forms as well as their elemental forms. ${ }^{11,12}$ Several factors have been determined to have an effect on the sorption of heavy metals onto the surface of biomass. Factors such as $\mathrm{pH}$, contact time, initial metal ion concentration, temperature, and common ions have been reported. ${ }^{13,14}$

Orange peel (Citrus sinensis), a flavonoid which belong to the class of polyphenolic compounds is extracted and is believed to have the active sites that could chelate with metal ions and thereby removing these metal ions from aqueous solutions. Orange peels are solid wastes which are often thrown away to litter the environment. When they are burnt they emit carbon particles, which constitute pollutants in the environment. The purpose of this work is therefore to investigate the potentials of the white inner skin of orange peel as an adsorbent for removing chromium and zinc from aqueous solution.

\section{Experimental Methods}

The adsorbent used for this study is the white inner skin of orange peel. The orange was brought at Rumuokwuta market Port Harcourt, Rivers State. The white inner skin of the orange peel were obtained by first peeling off the outer skin of the fresh fruits and then removing the inner fleshy layer after squeezing off the juice. Thereafter the peels were washed and air dried for seven days. The air -dried sample was later dried in Galen lamp oven at $70^{\circ} \mathrm{C}$ for $24 \mathrm{~h}$ to prevent denaturing of the cells. The oven dried sample was ground to fine powder using a grinding machine. It was sieved with a Tyler sieve of $106 \mu \mathrm{m}$ mesh to obtain fine particles.

The $106 \mu \mathrm{m}$ fine mesh inner skin of orange was activated by soaking $500 \mathrm{~g}$ in $500 \mathrm{ml}$ $0.3 \mathrm{M} \mathrm{HNO}_{3}$ for $24 \mathrm{~h}$ at room temperature. This was followed by washing sample thoroughly with distilled water until a pH of 6-8 was obtained. The sample was then filtered, air-dried and kept for the adsorption experiment. The $\mathrm{Cr}(\mathrm{V} 1)$ and $\mathrm{Zn}$ (11) ions solutions were prepared from an AR grade chromium trioxide $\left(\mathrm{CrO}_{3}\right)$ and zinc sulfate $\left(\mathrm{ZnSO}_{4} \cdot 7 \mathrm{H}_{2} \mathrm{O}\right)$. Distilled water was used for the preparation of all solutions and adsorption experiments. $1000 \mathrm{mgL}^{-1}$ stock solution of chromium (V1) and zinc (11) was prepared by dissolving $0.5195 \mathrm{~g}$ of $\mathrm{CrO}_{3}$ and $0.2278 \mathrm{~g}$ of $\mathrm{ZnSO}_{4} \cdot 7 \mathrm{H}_{2} \mathrm{O}$ in $1000 \mathrm{~cm}^{3}$ of distilled water. From the stock solutions, working solutions of initial concentration $\left(100 \mathrm{mgL}^{-1}\right)$ of each metal were prepared by serial dilution.

\section{Effect of Temperature}

$100 \mathrm{ml}$ chromium (V1) metal ion concentration of $100 \mathrm{mgL}^{-1}$ was measured into eight $250 \mathrm{ml}$ conical flasks. $1.0 \mathrm{~g}$ of the biomass with particle size $106 \mu \mathrm{m}$ was then weighed and 
added to these solutions. The flasks were agitated at $150 \mathrm{rpm}$ and heated on thermostatic water bath at $10,20,30,40,50,60$ and $70^{\circ} \mathrm{C}$ temperatures. The suspensions were then filtered using Whatman No. 40 filter paper, centrifuged for 5 minutes and analyzed. The same experiments were also carried out using $\mathrm{Zn}$ (11) ion.

\section{Effect of $p H$}

The effect of $\mathrm{pH}$ on the amount of $\mathrm{Cr}(\mathrm{V} 1)$ and $\mathrm{Zn}(11)$ metal ions was analyzed over the $\mathrm{pH}$ range from 1-7. In this study, $100 \mathrm{ml}$ metal ions concentration of $100 \mathrm{mgL}^{-1}$ was measured into $250 \mathrm{ml}$ conical flask and $1.0 \mathrm{~g}$ of the biomass was added and agitated at $150 \mathrm{rpm}$. The mixture were left in a water bath at $30^{\circ} \mathrm{C}$ for one hour. The solution was filtered using Whatman No. 40 filter paper and the residual metal ions concentration analyzed.

\section{Effect of contact time}

The effect of contact time on the removal of $\mathrm{Cr}(\mathrm{V} 1)$ and $\mathrm{Zn}$ (11) ions were carried out for a period of $2 \mathrm{~h}$ at a time interval of 20 minutes. Different masses of the biomass ranging from 0.2-1.4 g were accurately weighed and transferred into the $250 \mathrm{ml}$ conical flasks. 100 $\mathrm{mgL}^{-1}$ of metal ion solutions of $\mathrm{Cr}(\mathrm{V} 1)$ and $\mathrm{Zn}(11)$ were added to each of the conical flasks. The flasks were tightly covered with cellophane and shaken for 1 hour, the suspensions were filtered through Whatman No. 40 filter paper, centrifuged for 5 minutes and analyzed.

\section{Effect of metal ions concentrations}

In order to determine the effect of metal ions concentrations, $100 \mathrm{~mL}$ of various solutions ranging from $40-100 \mathrm{mgL}^{-1}$ were prepared in seven conical flasks for $\mathrm{Cr}(\mathrm{V} 1)$ and $\mathrm{Zn}$ (11) ions separately. One gram of the adsorbent was added to each flask, agitated for $1 \mathrm{~h}$, filtered, centrifuged for 5 minutes and analyzed with AAS. The initial $\mathrm{pH}$ of each of the solutions were adjusted to the optimum $\mathrm{pH}$ value by drop-wise addition of $0.1 \mathrm{M}$ sodium hydroxide and $0.1 \mathrm{M}$ nitric acid except for the experiment on the effect of $\mathrm{pH}$ where the study was carried out at different $\mathrm{pH}$ values. Fresh dilution of the stock solution was done for each biosorption study.

The results obtained were analyzed using Langmuir isotherm and the calibration was performed for each metal. Controls of each of the metal solutions were run to detect any metal precipitation or contamination the difference between the initial metal concentrations in supernatants was taken to be sorbed up by the biomass using a mass balance equation $(1) .^{15}$

$$
\% \mathrm{R}=\frac{C_{0}-C_{e}}{C_{0}} \times 100
$$

where, $\mathrm{R}$ is removal and $\mathrm{C}_{\mathrm{o}}$ and $\mathrm{C}_{\mathrm{e}}$ are the initial and equilibrium metal ion concentrations in solution.

The amounts of chromium and zinc metal uptake were computed using the following equation (2):

$$
\mathrm{qe}=\frac{v}{M}\left(C_{o}-C_{\theta}\right)
$$


where, $\mathrm{q}_{\mathrm{e}}(\mathrm{mg} / \mathrm{g})$ is the amount of chromium and zinc sorbed by the adsorbent. $\mathrm{C}_{\mathrm{o}}$ and $\mathrm{C}_{\mathrm{e}}(\mathrm{mg} / \mathrm{L})$ are the initial and equilibrium concentrations of the metal ions, respectively. $\mathrm{V}$ is the initial volume of metal ions concentration in litres and $\mathrm{M}(\mathrm{g})$ is the weight of the adsorbent.

\section{Results and Discussion}

The effect of temperature on the adsorption of $\mathrm{Cr}(\mathrm{VI})$ and $\mathrm{Zn}(\mathrm{II})$ ions is shown in Fig. 1 and Table 1. It shows that adsorption of $\mathrm{Cr}(\mathrm{VI})$ and $\mathrm{Zn}(\mathrm{II})$ metal ions by orange peel biomass is found to increase from $10-30^{\circ} \mathrm{C}$. The increase in adsorption capacity with temperature suggested that the optimal temperature is observed around $30^{\circ} \mathrm{C}$. High temperature increases entropy and this leads to reduction in the stability of metal ions, thereby increasing its randomness and consequently reducing the amount of heavy metal ions available for binding at elevated temperatures.

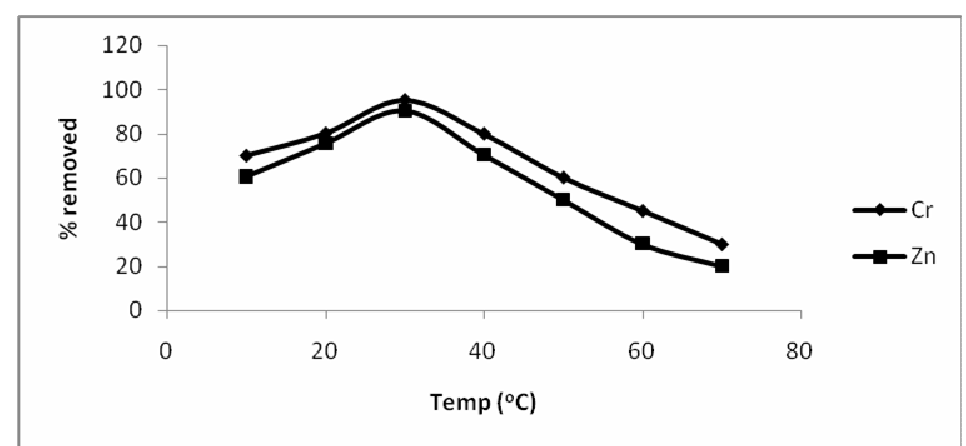

Figure 1: Effect of temperature on sorption behaviour of $\mathrm{Cr}$ (VI) and $\mathrm{Zn}$ (II) ions from solution (initial concentration $=100 \mathrm{mgL}^{-1}, \mathrm{pH}=3$, equilibrium time $=1 \mathrm{~h}$ ).

Table 1: Effect of temperature and $\mathrm{pH}$ on the sorption of metal ions

\begin{tabular}{|c|l|l|l|l|l|l|l|l|l|}
\hline $\begin{array}{c}\text { Temperature } \\
\left({ }^{\circ} \mathrm{C}\right)\end{array}$ & $\begin{array}{c}\text { Equilibrium } \\
\text { metal ions } \\
\text { concentration } \\
\left(\mathrm{C}_{\mathrm{e}}\right) \text { in } \mathrm{mg} / \mathrm{L}^{-1}\end{array}$ & $\begin{array}{c}\text { Percentage } \\
\text { metal ions } \\
\text { sorbed } \\
(\%)\end{array}$ & $\mathrm{pH}$ & \multicolumn{2}{|c|}{$\begin{array}{c}\text { Equilibrium } \\
\text { metal ions } \\
\text { Concentration } \\
\left(\mathrm{C}_{\mathrm{e}}\right) \text { in } \mathrm{mgL}^{-1}\end{array}$} & $\begin{array}{c}\text { Percentage } \\
\text { metal ions } \\
\text { sorbed } \\
(\%)\end{array}$ \\
\hline & $\mathrm{Cr}(\mathrm{VI})$ & $\mathrm{Zn}(\mathrm{II})$ & $\mathrm{Cr}(\mathrm{VI})$ & $\mathrm{Zn}(\mathrm{II})$ & & $\mathrm{Cr}(\mathrm{VI})$ & $\mathrm{Zn}(\mathrm{II})$ & $\mathrm{Cr}(\mathrm{VI})$ & $\mathrm{Zn}(\mathrm{II})$ \\
\hline 10 & 29.8 & 39.6 & 70.2 & 60.4 & 1 & 29.9. & 48.7 & 70.1 & 52.3 \\
\hline 20 & 19.7 & 24.7 & 80.3 & 75.3 & 2 & 24.5 & 35.9 & 75.5 & 64.1 \\
\hline 30 & 5.6 & 9.9 & 95.4 & 90.1 & 3 & 9.8 & 19.9 & 90.2 & 80.1 \\
\hline 40 & 19.9 & 29.7 & 80.1 & 70.3 & 4 & 19.6 & 28.8 & 80.4 & 70.2 \\
\hline 50 & 39.7 & 50.0 & 60.3 & 50.0 & 5 & 39.4 & 34.2 & 60.6 & 65.8 \\
\hline 60 & 54.5 & 79.9 & 45.2 & 30.1 & 6 & 46.7 & 39.6 & 54.3 & 60.4 \\
\hline 70 & 69.8 & 80.8 & 30.2 & 20.2 & 7 & 54.3 & 45.8 & 45.7 & 55.2 \\
\hline
\end{tabular}


The result of the $\mathrm{pH}$ study shows that maximum sorption occurred at $\mathrm{pH} 3$ for both $\mathrm{Cr}$ (VI) and $\mathrm{Zn}$ (II) metal ions as shown in Fig. 2 and Table 1. $80.1 \%$ of zinc ion was removed compared to $90.2 \%$ for chromium. The adsorptive capacities of $\mathrm{Cr}$ (VI) and $\mathrm{Zn}$ (II) ion increased rapidly as the $\mathrm{pH}$ increased.

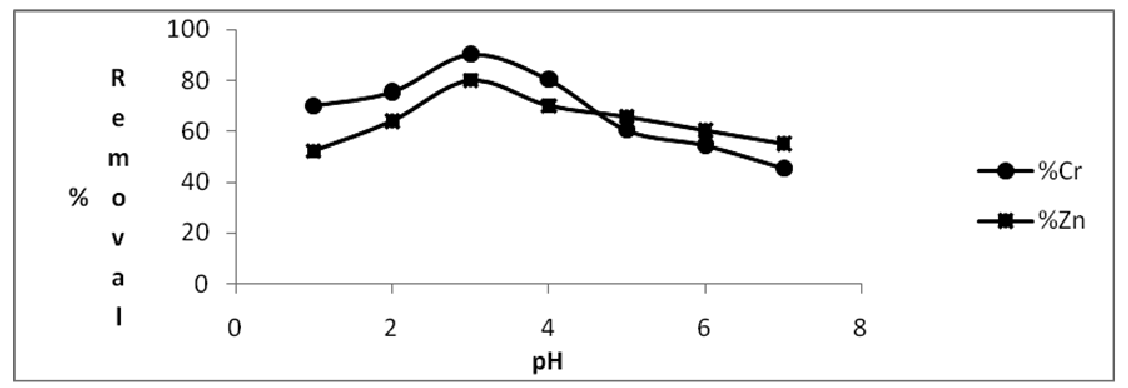

Figure 2: Effect of $p H$ on sorption behaviour of $C r(V I)$ and $\mathrm{Zn}(\mathrm{II})$ ions from solution (initial concentration $=100 \mathrm{mgL}^{-1}, \mathrm{pH}=3$, equilibrium time $=1 \mathrm{~h}$ )

The decrease in the adsorption with increase of $\mathrm{pH}$ may be due to the decrease in electrostatic force of attraction between the sorbent and sorbate ions. At lower $\mathrm{pH}$ ranges, due to the high electrostatic force of attraction, the percentage of $\mathrm{Cr}$ (VI) ion removal is high. At very low $\mathrm{pH}$ value, the surface of sorbent would also be surrounded by the hydronium ions which enhance the $\mathrm{Cr}(\mathrm{VI})$ interaction with binding sites of the adsorbent by greater attractive forces. A sharp decrease in adsorbents above $\mathrm{pH} 3$ may be due to occupation of the adsorption sites by anionic species which retards the approach of such ions further toward the sorbent surface. The decrease in adsorption at high $\mathrm{pH}$ values may be due to the competitiveness of the oxyanion of chromium and $\mathrm{OH}$ ions in the bulk. As the $\mathrm{pH}$ increased, the overall surface charge on the orange peel became negative and adsorption decreases.

The relationship between contact time and the percentage removal of chromium and zinc metal ions from solution by orange peel biomass is presented in Fig. 3. At a time interval of $20 \mathrm{~min}$ and an initial metal ion concentration of $100 \mathrm{mgL}^{-1}$, adsorption increased very fast and decreased with increase in time.

It therefore showed that the best contact time for adsorption using orange peel biomass with $\mathrm{Cr}$ (VI) and $\mathrm{Zn}$ (II) is 30 minutes. It proves that the individual metal ions bound to the orange peel waste in less than 30 minutes and remained stable. The rapid uptake of metal ions in solution by biomaterials may be due to the fact that binding occurred on the cell walls of the biomass. This difference may have resulted from the nature of the biomass used. The percentage chromium removal was $85 \%$ and above $80 \%$ removal for zinc.

The effect of adsorbent dosage is shown in Fig. 4. The percentage of chromium and zinc ions removable is increased with increasing adsorbent dosage until the surface became saturated and further increase had no effect. The increase was highest with $1 \mathrm{~g}$ removing $97.6 \%$ chromium and $92.3 \%$ of zinc. This can be explained by a greater availability of exchangeable sites or surface area at higher amount of the adsorbent. 


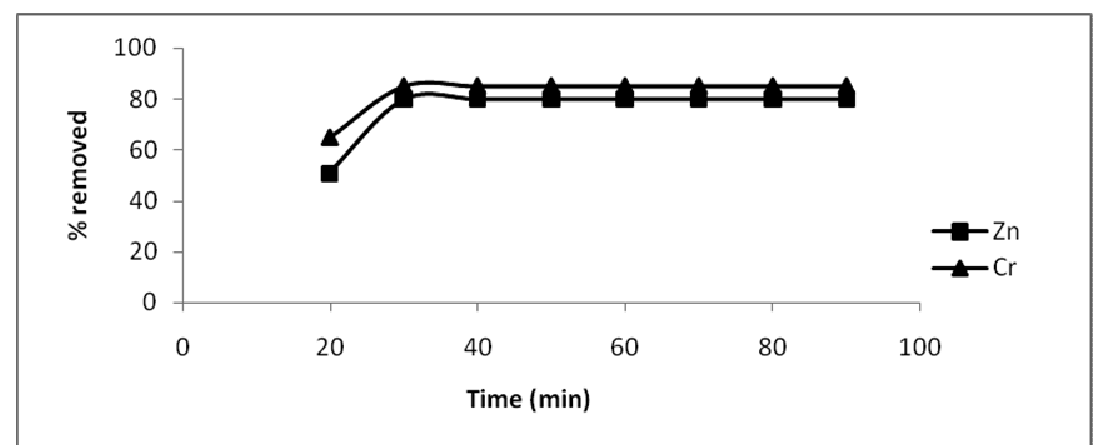

Figure 3: Effect of contact time on the percentage removal of $\mathrm{Cr}(\mathrm{VI})$ and $\mathrm{Zn}$ (II) ions from solution. (Initial concentration $=100 \mathrm{mgL}^{-1}, \mathrm{pH}=3$, temp $=30^{\circ} \mathrm{C}$ )

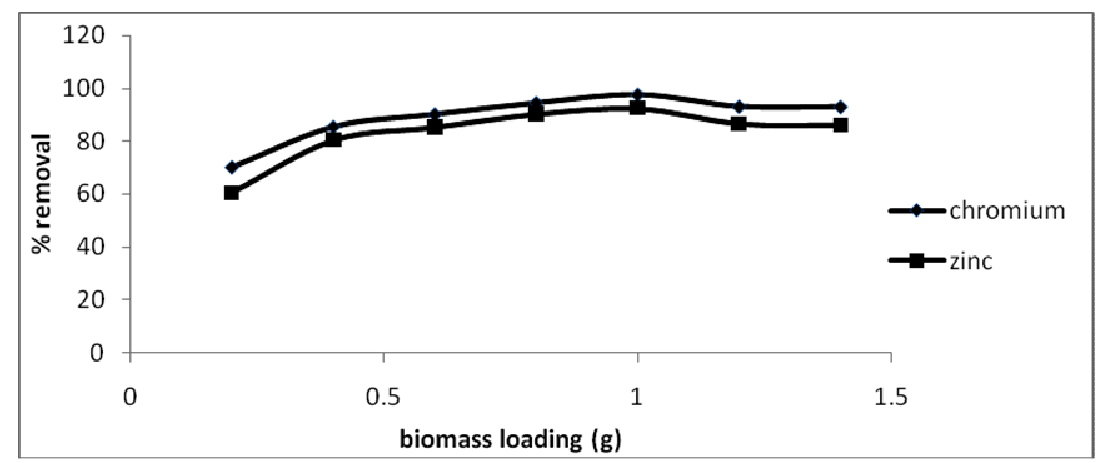

Figure 4: Effect of adsorbent dosage on sorption behaviour of $\mathrm{Cr}$ (VI) and $\mathrm{Zn}$ (II) ions from solution (initial concentration $=100 \mathrm{mgL}^{-1}, \mathrm{pH}=3$, equilibrium time $=1 \mathrm{~h}$ )

Figure 5 shows that the removable efficiency decreases with increasing initial concentrations from 40-100 $\mathrm{mgL}^{-1}$. This means the maximum adsorption occurred at minimum concentration of metal ions. It may be so because of greater number of ions in solution and thus leading to desorption of the metal ions from the binding sites of adsorbent particles. Whereas with limited number of ions there is limited number of collisions between the metal ions that is why low concentration of metal ions showed higher adsorption rate.

The capacity of the orange peel biomass was modelled using linearlized Langmuir isotherm equation (3) as given below:

$$
\frac{\mathrm{C}_{\mathrm{e}}}{\mathrm{q}_{\mathrm{e}}}=\frac{1}{\mathrm{q}_{\mathrm{m}} \mathrm{K}_{\mathrm{L}}}+\frac{\mathrm{C}_{\mathrm{e}}}{\mathrm{q}_{\mathrm{m}}}
$$

where, $\mathrm{q}_{\mathrm{m}}$ and $\mathrm{K}_{\mathrm{l}}$ are the Langmuir constants.

Figure 6 shows the linealized fit of the Langmuir equation. The plots of specific sorption $\left(\mathrm{C}_{\mathrm{e}} / \mathrm{q}_{\mathrm{e}}\right)$ against equilibrium concentration $\left(\mathrm{C}_{\mathrm{e}}\right)$ gave the linear isotherm parameters of $\mathrm{q}_{\mathrm{m}}, \mathrm{K}_{\mathrm{L}}$ and the coefficient of determination and are presented in Table 2 also. 


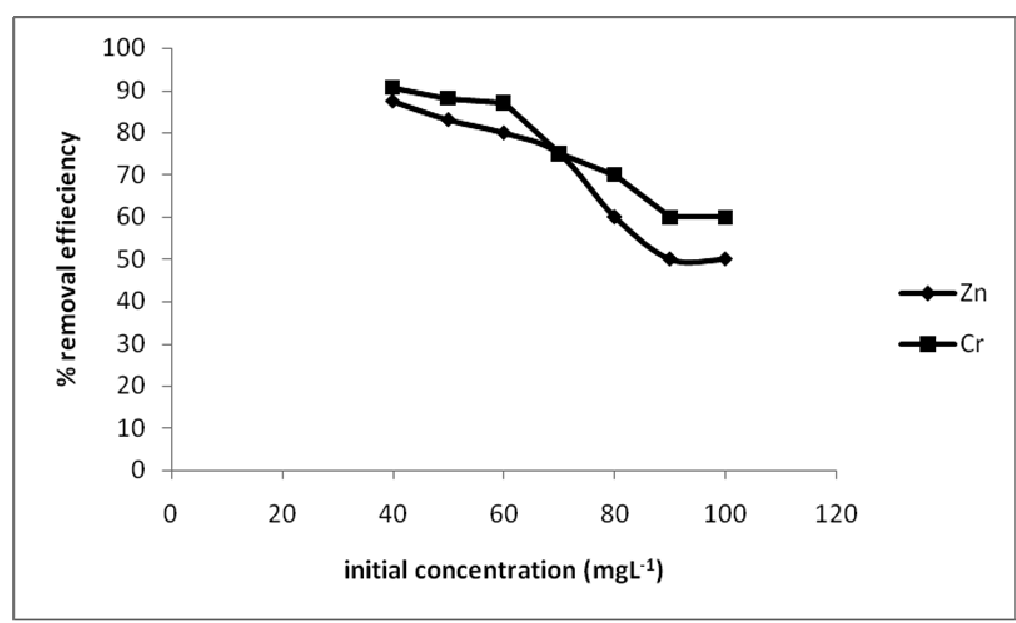

Figure 5: Effect of initial concentrations on sorption behaviour of $\mathrm{Cr}$ (VI) and $\mathrm{Zn}$ (II) ions from solution (initial concentration 40-100 $\mathrm{mgL}^{-1}, \mathrm{pH}=3$, equilibrium time $=1 \mathrm{~h}$ )

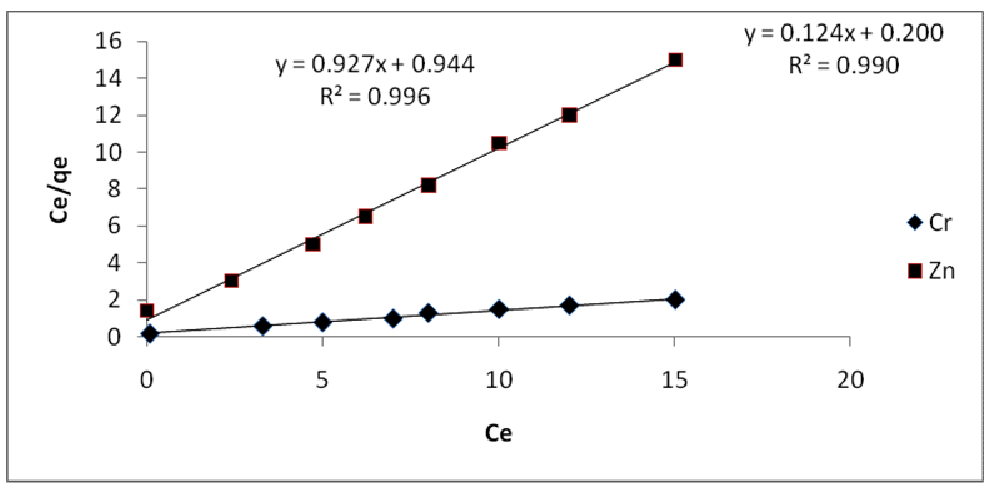

Figure 6: Langmuir isotherm plot for $\mathrm{Cr}(\mathrm{VI})$ and $\mathrm{Zn}(\mathrm{II})$

Table 2: Langmuir isotherm parameters

\begin{tabular}{|l|l|l|l|l|}
\hline Metal ions & $\mathbf{q}_{\mathbf{m}}(\mathbf{m g} / \mathbf{g})$ & $\mathbf{K}_{\mathbf{L}}(\mathbf{L} / \mathbf{m g})$ & $\mathbf{R}^{2}$ & $\mathbf{S}_{\mathbf{F}}$ \\
\hline $\mathrm{Cr}^{6+}$ & 8.068 & 0.619 & 0.990 & 0.03 \\
\hline $\mathrm{Zn}^{2+}$ & 1.078 & 0.982 & 0.996 & 0.01 \\
\hline
\end{tabular}

The Langmuir isotherm model was chosen for the estimation of adsorption capacity corresponding to complete monolayer coverage on the biomass surface. The sorption capacity $\left(\mathrm{q}_{\mathrm{m}}\right)$ which is a measure of the maximum sorption capacity corresponding to complete monolayer coverage showed that orange peel has a mass capacity for $\mathrm{Cr}(\mathrm{VI})$ and $\mathrm{Zn}$ (II) are $8.068 \mathrm{mg} \mathrm{g}^{-1}$ and $1.078 \mathrm{mg} \mathrm{g}^{-1}$, respectively. The adsorption coefficient $\left(\mathrm{K}_{\mathrm{L}}\right)$ that is related to the apparent energy of sorption for $\mathrm{Zn}$ (II) is found to be greater than that of $\mathrm{Cr}(\mathrm{VI})$ 
probably due to its large ionic radius. Hence not all binding sites may be available to $\mathrm{Zn}$ (II). The same capacity order had been reported for different metal ion sorption on modified coconut noir and cassava waste biomass ${ }^{16,17}$. The data presented in Table 2 further indicates that the effectiveness of orange peel waste in the sorption of the two metals from aqueous system was $\mathrm{Cr}(\mathrm{VI})>\mathrm{Zn}$ (II). This preferential sorption behaviour could be explained in terms of ionic radii of the metal ions $\mathrm{Cr}(\mathrm{VI})[0.069 \AA]$ and $\mathrm{Zn}(\mathrm{II})[0.074 \AA$ ㅇ․ The element with smaller ionic radius will compete faster for exchange sites than those of larger ionic radius. The larger the charge of an ion, the smaller the ionic radius, hence the charge of an ion may influence its ability to sorb on biosorbents. The observed order indicates that $\mathrm{Cr}$ (VI) may have greater accessibility to the surface of certain pores than $\mathrm{Zn}$ (II) due to its smaller ionic radius. ${ }^{18-19}$

Further more favourability of adsorption of the metal ions on the white inner skin of orange peel biomass was tested using the essential features of the Langmuir isotherm model, expressed in terms of a dimensionless constant called separation factor $\mathrm{S}_{\mathrm{F}}$, which is defined by the following relationship.

$$
\mathrm{S}_{\mathrm{F}}=\frac{1}{1+\mathrm{K}_{\mathrm{L}} \mathrm{C}_{\mathrm{o}}}
$$

where, $\mathrm{K}_{\mathrm{L}}=$ Langmuir isotherm constant: $\mathrm{C}_{\mathrm{o}}=$ initial metal concentration.

The separation parameters for the two metals are less than unity indicating that orange peel waste biomass is an excellent adsorbent for the two metal ions removal.

\section{Conclusions}

The following conclusions are drawn from the above results and discussion:

1. Adsorbent prepared from orange peel could be used for the removal of $\mathrm{Cr}(\mathrm{VI})$ and $\mathrm{Zn}$ (II) in aqueous solution.

2. The maximum adsorption of $\mathrm{Zn}(\mathrm{II})$ and $\mathrm{Cr}(\mathrm{VI})$ was at $\mathrm{pH} 3$.

3. Adsorption process of $\mathrm{Cr}(\mathrm{VI})$ and $\mathrm{Zn}$ (II) in aqueous solution can be described by Langmuir isotherm model

4. Adsorption of $\mathrm{Cr}(\mathrm{VI})$ and $\mathrm{Zn}$ (II) yielded maximum adsorption capacity of $8.068 \mathrm{mg} / \mathrm{g}$ and $1.078 \mathrm{mg} / \mathrm{g}$, respectively.

5. Removal of $\mathrm{Cr}(\mathrm{VI})$ and $\mathrm{Zn}(\mathrm{II})$ increases with increase of adsorbent dosage.

\section{References}

1. E. U. Ikhuoria and F. E. Okieimen, Inter. J. Environ studies., 2000, 57, 401

2. T. A. Arowolo, West. Indian. Med. J., 2004, 52, 63

3. J. O. Nriagu, African. Sci .,1996, 223, 272

4. A. A. Abia and E. D. Asuquo, Afric. J. Biotechnol., 2006, 16, 1475

5. T. Vanghan, C.W. Seos and W. E . Marshall, Bioresources Tech., 2001, 78, 133

6. N. A. Babarinde, J. O. Babalola and R. A. Sanni, Int .J. Phy. Sci., 2006, 1, 23 
7. A . M. Moshen, Int. J. Phys. Sci., 2000, 7, 178

8. S. Khatoon, J. Anwas, M. Hassan, R. Farooq, H. Fatima and H. Kalid, World App. Sci. J., 2009,12, 1638

9. K. E. Ozioma, The Effect of contact Time and $\mathrm{pH}$ on the removal of $\mathrm{Cr}$ (VI) and $\mathrm{Mn}$ (II) from aqueous solution using water Hyacinth. A Project Submitted to The Department of Pure and Industrial Chemistry. University of Port Harcourt. Nigeria, Unpublished Project. 2005, Pp. 67

10. M. H. Kalavathy, T. Karthikeyan, S. Rajoagopal and L. R. Miranda. J. Colloid. Interface. Sci., 2005, 292, 354

11. N. A. A.Babarinde, J. O. Babalola and A. A. Adetunji, The Pacific J. Sci. Technol., 2008, 9, 196

12. P. Vasuderan, V. Padmavathy and S. C. Dhingra, Bioresour. Technol., 2003, 89, 281.

13. H. Xu, Y. Liu and J. Tay, Bioresour.Technol., 2006, 97, 359.

14. Y. S. Ho and G. McKay, Water Resource., 2000, 34, 735

15. P. Pavasant, R. Apiratikul, V. Sungkhum, P. Suthiparinyanont, S. Wattannchira and T. Marhaba, Bioresour Technol., 2006, 97, 23

16. N. A. Babarinde, J. O. Babalola, A. Adenike and A. Adetunji, Pacific. Sci. Tech., $2008,9,196$

17. M. Horsfall Jnr, A. I. Spiff and A. A. Abia, Bull Korean. Chem., Soc., 2004, 25, 969

18. D. D. Das, R. Mahapatra, J. Pradhan, S. N. Das and R. S. Thakur, J. Colloid Interface Sci., 2000, 232, 235

19. Y.S. Ho and G. McKay, Water Resource., 2000, 34,735 